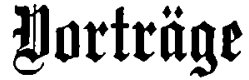

\section{doer theolugildati}

\author{
gebalten am 5. Suni 1890.
}

(VI. Folge.)

(Sonfiftrialrath D. Hudolph Ehlers (Franffurt a. פM.) :

Das neue Teftament uno die Taufe.

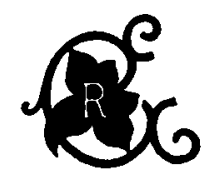

Giekent

3. Hider'ide Budlyaublung.

1890. 
